\title{
Generation of Elemental Fluorine through the Electrolysis of Copper Difluoride at Room Temperature
}

\section{$\operatorname{AUTHOR}(S)$ :}

Matsumoto, Kazuhiko; Shima, Keita; Sugimoto, Takuya; Inoue, Takahiro; Hagiwara, Rika

\section{CITATION:}

Matsumoto, Kazuhiko ... [et al]. Generation of Elemental Fluorine through the Electrolysis of Copper Difluoride at Room Temperature. Angewandte Chemie International Edition 2021, 60: 7887-7892

\section{ISSUE DATE:}

2021-03-29

URL:

http://hdl.handle.net/2433/262423

\section{RIGHT:}

This is the peer reviewed version of the following article: K. Matsumoto, K. Shima, T. Sugimoto, T. Inoue, R. Hagiwara, Angew. Chem. Int. Ed. 2021, 60, 7887, which has been published in final form at https://doi.org/10.1002/anie.202016463. This article may be used for non-commercial purposes in accordance with Wiley Terms and Conditions for Use of SelfArchived Versions.; The full-text file will be made open to the public on 26 February 2022 in accordance with publisher's 'Terms and Conditions for Self-Archiving'.:. This is not the published version. Please cite only the published version. この 論文は出版社版でありません。引用の際には出版社版をご確認ご利用ください。 


\title{
Generation of elemental fluorine through the electrolysis of copper difluoride at room temperature
}

\author{
Kazuhiko Matsumoto, ${ }^{[a]}$ Keita Shima, ${ }^{[a]}$ Takuya Sugimoto, ${ }^{[a]}$ Takahiro Inoue, ${ }^{\left[{ }^{[a]}\right.}$ and Rika Hagiwara ${ }^{[a]}$
}

[a] Prof. K. Matsumoto, Mr. K. Shima, Mr. T. Sugimoto, Mr. T. Inoue, Prof. R. Hagiwara

Graduate School of Energy Science

Kyoto University

Yoshida, Sakyo-ku, Kyoto 606-8501 (Japan)

E-mail: k-matsumoto@energy.kyoto-u.ac.jp

Supporting information for this article is given via a link at the end of the document.

\begin{abstract}
The safe generation of $F_{2}$ gas at room temperature using simple cell configurations has been the 'holy grail' of fluorine research for centuries. Thus, to address this issue, we report $\mathrm{F}_{2}$ gas generation through the electrolysis of $\mathrm{CuF}_{2}$ in a CsF-2.45HF molten salt without the evolution of $\mathrm{H}_{2}$ gas. The $\mathrm{CuF}_{2}$ is selected through a series of thermodynamic and kinetic assessments of possible metal fluorides. Anode assessments on graphite and glass-like carbon demonstrate absence of the anode effect during $F_{2}$ gas generation due to stabilized operations at room temperature. Although $\mathrm{Ni}$ anode dissolves during electrolysis in the conventional medium-temperature cell, herein, it facilitates stable electrolysis over $100 \mathrm{~h}$, achieving the $\mathrm{F}_{2}$ gas purity over $99 \%$ with potential operation using one-compartment electrolysis. This work presents a safe and propitious mechanism for high-purity fluorine gas generation for small-scale lab and industrial applications.
\end{abstract}

\section{Introduction}

For years, elemental fluorine has been revered for its remarkable reactivity, which makes it uniquely pertinent in expansive applications ranging from the exploration of new chemistries in pioneering studies to practical operations such as the preparation of inorganic compounds, for instance, hexafluorides (e.g., $\mathrm{UF}_{6}$ and $\mathrm{SF}_{6}$ ), carbon fluorides and noble gas fluorides, ${ }^{[1]}$ the direct fluorination of organic substrates, ${ }^{[1 a, 2]}$ as well as in the surface treatment of functional materials. ${ }^{[3]}$ Despite its immense potential, the practical production and use of fluorine are mired by safety issues during handling, limiting the methodologies and materials used.

The advancement of fluorine production has been particularly slow. Despite being envisioned decades earlier, fluorine was first isolated by a French Nobelist, Henri Moissan, in 1886 through the electrolysis of an HF electrolyte containing KF as a supporting electrolyte. ${ }^{[4]}$ Therein, $\mathrm{H}_{2}$ and $\mathrm{F}_{2}$ gases were generated at the cathode and anode, respectively, in accordance with Equations. (1) and (2):

\section{Cathode: $2 \mathrm{H}^{+}+2 \mathrm{e}^{-} \rightarrow \mathrm{H}_{2}$ \\ Anode: $2 \mathrm{~F}^{-} \rightarrow \mathrm{F}_{2}+2 \mathrm{e}^{-}$}

Total: $2 \mathrm{HF} \rightarrow \mathrm{H}_{2}+\mathrm{F}_{2}$
Notwithstanding the momentous breakthrough by Moissan, it was not until 1986, a hundred years later, that the first chemical synthesis of $F_{2}$ gas was achieved through the thermal decomposition of $\mathrm{MnF}_{4}$ prepared from the Lewis acid-base reaction of $\mathrm{K}_{2} \mathrm{MnF}_{6}$ and $\mathrm{SbF}_{5}$, as reported by Christe..$^{[5]}$ In another noteworthy milestone reported by Kraus et al. in 2012, $F_{2}$ gas was found to emanate from antozonite, a type of fluorite containing radioactive species, indicating that the elusive halogen gas could be generated through the irradiation of fluorides. ${ }^{[6]}$ More recent works on this topic explored detailed assessments of the crystal structure of $\mathrm{F}_{2}$ through experimental and theoretical techniques. ${ }^{[7]}$

Despite the tremendous efforts to industrialize $F_{2}$ gas generation, the basic reaction involving the electrolysis of $\mathrm{HF}$, as reported by Moissan, remains unchanged. ${ }^{[8]}$ Advancements in $F_{2}$ gas production are mainly focused on electrolyte development to optimize operation temperatures, determine anode material, and improve safety. In the current industrial $\mathrm{F}_{2}$ production, KF-2HF molten salt at medium temperatures $\left(90^{\circ} \mathrm{C}\right)$ is used under controlled HF dissociation pressure $\left(5 \times 10^{3} \mathrm{~Pa}\right.$ at $90{ }^{\circ} \mathrm{C}$, the extrapolated value from the data at $98.7,118.2$, and $128.6{ }^{\circ} \mathrm{C}$ ) and maintained liquid state (melting point $71.7{ }^{\circ} \mathrm{C}$ ). ${ }^{[9]}$ Carbonaceous materials have found niche utility as anodes on account of their resistivity against oxidation by $F_{2}$ gas. Even so, these anode materials are still afflicted by surface fluorination, which results in the so-called "anode effect" characterized by the formation of an insulating film with a small surface energy that causes sharp increases in the anode potential. ${ }^{[8 c]}$ For safe deployment, various electrolysis cell configurations have also been developed to ensure complete separation of $\mathrm{F}_{2}$ and $\mathrm{H}_{2}$ gases evolved at the anode and cathode, respectively. $\left.{ }^{[8 a}, 8 \mathrm{~b}\right]$

An alternative approach reported in 1934 proposed the use of CsF-2HF molten salt electrolyte for $\mathrm{F}_{2}$ gas generation, including metal fluoride electrolysis. ${ }^{[10]}$ In the full phase diagram of the CsF$\mathrm{HF}$ system reported, the liquidus line was found to drop below room temperature around the composition of CsF-2.45HF, indicating the possibility of room-temperature operations. ${ }^{[11]}$ Although a report in 2006 compared the properties of a CsF2.3HF molten salt with non-volatile ionic liquid [1-alkyl-3methylimidazolium $]\left[(\mathrm{FH})_{2.3} \mathrm{~F}\right]$ showing high ionic conductivity and low HF dissociation pressure in the CsF-2.3HF molten salt, ${ }^{[12]}$ successive reports on this $\mathrm{Cs}$ system cannot be found. This could be attributed to the high cost of CsF that limits the practicality of the CsF-HF system. However, the growing focus on safety and 
(a)

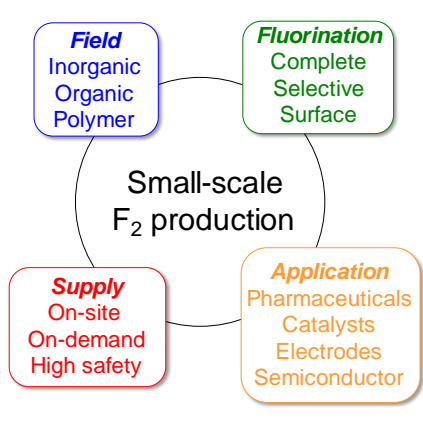

(b)

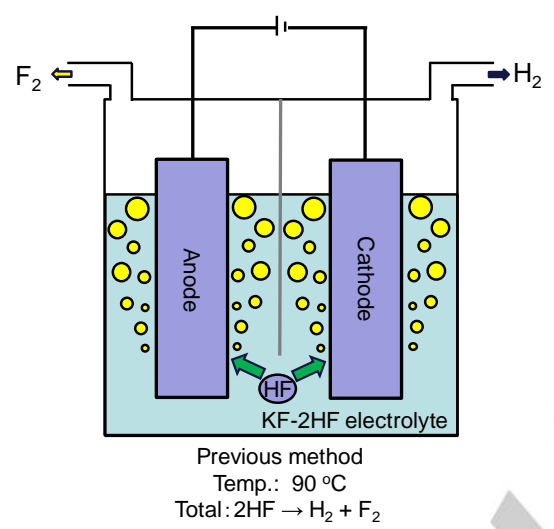

(c)

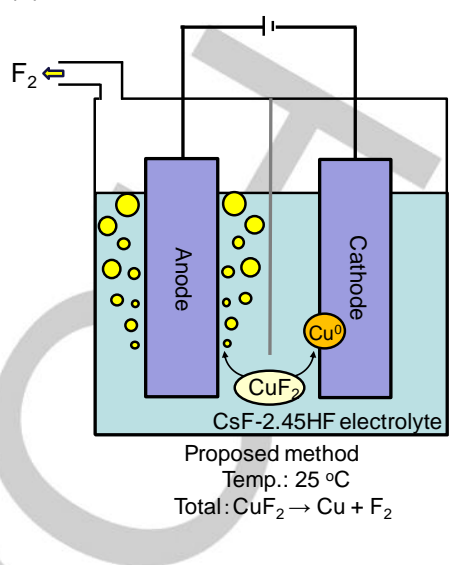

Figure 1. (a) Illustration showing the significance of small-scale $F_{2}$ gas production. Schematic drawings of the (b) previous and (c) proposed $F_{2}$ gas generation methods. In the previous method, $\mathrm{HF}$ is electrolyzed into $\mathrm{H}_{2}$ and $\mathrm{F}_{2}$ in the $\mathrm{KF}-2 \mathrm{HF}$ molten salt at $90{ }^{\circ} \mathrm{C}$, whereas the proposed method enables room-temperature electrolysis of $\mathrm{CuF}_{2}$ with the aid of room-temperature molten salt, $\mathrm{CsF}-2.45 \mathrm{HF}$. Absence of $\mathrm{H}_{2}$ gas evolution at the cathode leads to high safety in the proposed method.

the versatility of applications have shifted academic and industrial demands towards in-situ and on-demand generation or storage of small quantities of $F_{2}$ gas as illustrated by Figure 1(a). At this scale, low currents below $1 \mathrm{~A}$ could be utilized, minimizing the cost of the CsF-HF system. Most importantly, this approach would provide an avenue for room-temperature generation of $F_{2}$ gas without temperature controller.

In a bid to exploit this approach, this study reports the generation of $F_{2}$ gas through the electrolysis of CsF-2.45HF molten salt containing $\mathrm{CuF}_{2}$ at room temperatures. Schematics showing a comparison between the previous $F_{2}$ generation processes and the system proposed in this study are furnished in Figure 1 (b) and (c), respectively. We ascertain that the composition of CsF-2.45HF corresponds to the eutectic point in the phase diagram with a eutectic temperature of $16.9^{\circ} \mathrm{C} .{ }^{[11]} \mathrm{By}$ using $\mathrm{CuF}_{2}, \mathrm{H}_{2}$ gas evolution at cathode is inhibited, significantly improving the safety of operations while unveiling the possibility of one-compartment electrolysis (electrolysis without partitioning the electrodes by a skirt). Screening of metal fluorides based on thermodynamic calculations, electrode behavior in the cathodic and anodic reactions, confirmation of purity, and possibility of onecompartment electrolysis will be discussed in details.

\section{Results and Discussion}

Ionic conductivity and viscosity measurements conducted on CsF-2.45HF revealed a sufficiently high ionic conductivity ( $86 \mathrm{mS}$ $\mathrm{cm}^{-1}$ ) and low viscosity (19 $\mathrm{mPa} \mathrm{s}$ ) for electrolysis at $25^{\circ} \mathrm{C}$ (cf. ionic conductivity at $25^{\circ} \mathrm{C}$ : $109 \mathrm{mS} \mathrm{cm}^{-1}$ for $1 \mathrm{~mol} \mathrm{~kg}^{-1}$ aqueous solution of $\mathrm{KCl}^{,[13]} 14 \mathrm{mS} \mathrm{cm}^{-1}$ for a typical ionic liquid, [1-ethyl-3methylimidazolium][BFF ${ }_{4}{ }^{[14]}$ and $10.8 \mathrm{mS} \mathrm{cm}^{-1}$ for $1 \mathrm{~mol} \mathrm{dm}^{-3}$ ethylene carbonate/dimethyl carbonate (1:1 in vol.) solution of $\left.\mathrm{Li}\left[\mathrm{PF}_{6}\right]^{[15]}\right)$. The molten salt was also confirmed to have a low HF dissociation pressure below $1 \mathrm{kPa}$.

The redox potentials (Figure 2(a)) of selected $\mathrm{MF}_{n} / \mathrm{M}$ or
$\mathrm{MF}_{n} / \mathrm{MF}_{m}(\mathrm{M}=\mathrm{Ag}, \mathrm{Cu}$, and $\mathrm{Fe})$ couples were calculated from thermodynamic data (see Table S1, Supporting Information, for estimation of the redox potentials). Although the availability of the redox couples can be obtained by evaluating the overpotential of $\mathrm{H}_{2}$ gas evolution, in this study, initial estimations were derived from available data for safety. From the thermodynamic data, the $\mathrm{AgF} / \mathrm{Ag}$ and $\mathrm{CuF}_{2} / \mathrm{Cu}$ redox potentials are noted to be above the $\mathrm{HF} / \mathrm{H}_{2}$ redox potential $\left(0.85\right.$ and $0.25 \mathrm{~V}$ vs. $\mathrm{HF} / \mathrm{H}_{2}$, respectively), whereas the $\mathrm{FeF}_{3} / \mathrm{FeF}_{2}, \mathrm{FeF}_{3} / \mathrm{Fe}$, and $\mathrm{FeF}_{2} / \mathrm{Fe}$ exhibit redox potentials below the $\mathrm{HF} / \mathrm{H}_{2}$ redox potential $(-0.40,-0.56$, and $-0.64 \mathrm{~V}$ vs. $\mathrm{HF} / \mathrm{H}_{2}$, respectively).

Typically, metal fluorides with higher redox potentials than $\mathrm{HF} / \mathrm{H}_{2}$ are preferred as they are less susceptible to $\mathrm{H}_{2}$ gas evolution. X-ray fluorescence spectroscopy data indicated the solubilities of $\mathrm{AgF}, \mathrm{CuF}_{2}, \mathrm{FeF}_{3}$, and $\mathrm{FeF}_{2}$ in $\mathrm{CsF}-2.45 \mathrm{HF}$ to be $2.8 \times 10^{-3}, 2.6 \times 10^{-1}, 1.3 \times 10^{-1}$, and $5.6 \times 10^{-2} \mathrm{~mol} \mathrm{~kg}^{-1}$, respectively. Thus, it can be deduced that $\mathrm{AgF}$ and $\mathrm{FeF}_{2}$, as the metal fluoride candidates for electrolysis in the present process, would be unfavorable due to their low solubilities. Another drawback of using $\mathrm{FeF}_{2}$ (or other metal fluorides at a low oxidation state) is the possible occurrence of a shuttle effect between the cathode and anode, whereby the metal fluoride at the anode is oxidized, causing deterioration of the anode current efficiency.

To assess the reduction of $\mathrm{CuF}_{2}$ or $\mathrm{FeF}_{3}$ in $\mathrm{CsF}-2.45 \mathrm{HF}$, cyclic voltammograms of a $\mathrm{Ni}$ plate electrode were obtained from the respective metal fluoride systems, as shown in Figure 2 (b) and (c). Details of the cell setup and gas line are furnished in the Supporting Information (Figures S1 and S2) and the CsF-2.45HF saturated with metal fluorides was used for this measurements. The electrode potential is referenced to the apparent $\mathrm{H}_{2}$ gas evolution potential estimated by linearly extrapolating the $\mathrm{H}_{2}$ gas evolution curve. In the $\mathrm{CuF}_{2}$-system (Figure 2 (b)), the cathodic wave representing $\mathrm{CuF}_{2}$ reduction is notably separated from the $\mathrm{H}_{2}$ gas evolution wave, whereas the $\mathrm{FeF}_{3}$ reduction and $\mathrm{H}_{2}$ gas evolution reactions overlap each other in the $\mathrm{FeF}_{3}$-system (Figure 2 (c)). These observations demonstrate $\mathrm{CuF}_{2}$ reduction as a 
(a)

$$
\begin{aligned}
& E / \mathrm{V} \text { vs. } \mathrm{HF} / \mathrm{H}_{2} \\
& \mathrm{~F}_{2} / \mathrm{F}^{-} 2.81 \rightarrow \uparrow \\
& \begin{array}{lll}
\tilde{\mathrm{TF}} / \mathrm{H}_{2} \quad 0-0.86 \mathrm{AgF} / \mathrm{Ag} \\
& \leftarrow 0.26 \mathrm{CuF}_{2} / \mathrm{Cu} \\
& \leftarrow-0.38 \mathrm{FeF}_{3} / \mathrm{FeF} \\
& \leftarrow-0.55 \mathrm{FeF}_{3} / \mathrm{Fe} \\
& \leftarrow-0.63 \mathrm{FeF}_{2} / \mathrm{Fe}
\end{array}
\end{aligned}
$$

(b)

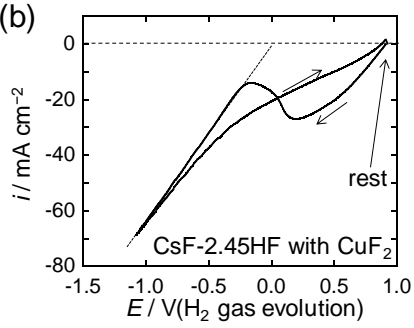

(c)

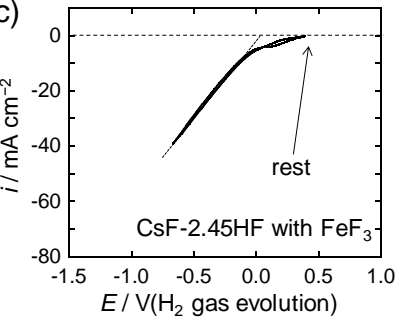

Figure 2. (a) Redox potentials of selected $M_{x} F / M\left(M\right.$ : metal) and $F_{2} / F^{-}$couples and cyclic voltammograms of a Ni plate electrode in the CsF-2.45HF molten salt containing (b) $\mathrm{CuF}_{2}$ and (c) $\mathrm{FeF}_{3}$ (see Figure S1, Supporting Information, for the cell setup). Metal fluorides were saturated in both the cases. Metal fluorides with redox potentials above $\mathrm{HF} / \mathrm{H}_{2}$ are preferable to avoid $\mathrm{H}_{2}$ gas generation at the cathode. See Table S1 and related discussion in Supporting Information for thermodynamic estimation of these redox potentials. The potential in the horizontal axis of (b) and (c) is roughly referenced to the potential of $\mathrm{H}_{2}$ gas evolution by linearly extrapolating the $\mathrm{H}_{2}$ gas evolution curve. The reduction current of $\mathrm{CuF}_{2}$ is significantly larger than that of $\mathrm{FeF}_{3}$ in the range above the $\mathrm{H}_{2}$ gas evolution potential.

feasible cathodic reaction, while $\mathrm{FeF}_{3}$ reduction is encumbered by the competitive $\mathrm{H}_{2}$ gas evolution. Therefore, $\mathrm{CuF}_{2}$ was selected as the metal fluoride to be electrolyzed in the present process under the following reaction equations (see cyclic voltammograms showing the $\mathrm{F}_{2}$ gas evolution behavior of glasslike carbon and $\mathrm{Ni}$ electrodes in $\mathrm{CsF}-2.45 \mathrm{HF}$ containing $\mathrm{CuF}_{2}$ in Figure S3):

Cathode: $\mathrm{Cu}^{2+}+2 \mathrm{e}^{-} \rightarrow \mathrm{Cu}$

Anode: $2 \mathrm{~F}^{-} \rightarrow \mathrm{F}_{2}+2 \mathrm{e}^{-}$

Total: $\mathrm{CuF}_{2} \rightarrow \mathrm{Cu}+\mathrm{F}_{2}$

To ascertain the electrodeposition behavior of $\mathrm{Cu}$ metal in the present system, potentiostatic electrolysis was performed on a $\mathrm{Ni}$ working electrode at $-0.5 \mathrm{~V}$ vs. $\mathrm{CuF}_{2} / \mathrm{Cu}$ ( $17.3 \mathrm{C}$ cumulatively). A red-brown deposit observed on the electrode was confirmed to be Cu metal through X-ray diffraction (Figure S4). To understand the basic electrochemical behavior of the entire cell, short-term electrolysis (up to 1000s) was performed on the CsF-2.45HF molten salt containing $\mathrm{CuF}_{2}$ in a $10 \mathrm{~cm}^{3}$ cell at $100 \mathrm{~mA}$. The potential of the Cu cathode (surface area: $24 \mathrm{~cm}^{2}$ ) was maintained between -0.1 and $-0.2 \mathrm{~V}$, while that of the glass-like carbon anode (surface area: $4.7 \mathrm{~cm}^{2}$ ) was kept around $8 \mathrm{~V}$ as long as a sufficient amount of $\mathrm{CuF}_{2}$ was available (see Figure S5 (a) and (b)). The gas generated at the anode was qualitatively identified as $\mathrm{F}_{2}$ gas through a reaction with $\mathrm{KI}$ (see Figure $\mathrm{S} 6$ for the visual change of the $\mathrm{KI}$ column). Consumption of over $96 \%$ of $\mathrm{CuF}_{2}$ was confirmed by monitoring the cathode potential; the cathode potential started to decline to $-0.4 \mathrm{~V}$ vs. $\mathrm{Cu}(\mathrm{II}) / \mathrm{Cu}$ owing to the deficiency of $\mathrm{CuF}_{2}$, as the quantity of electricity had reached a theoretical value corresponding to the full consumption of $\mathrm{CuF}_{2}$ initially added (see Figure S5(c) for the cathode potential profile at the end of electrolysis). The Cu deposit was also noted to grow towards the bottom of the cell because of the electric flux detour around the skirt (see Figure S5 (d)).

A serious problem facing typical $F_{2}$ gas generation through the electrolysis of KF-2HF systems utilizing carbon anodes is the socalled "anode effect", whereby a passivation layer of fluorinated carbon is formed on the surface of the carbon anode, $\left.{ }^{[1 d,} 16\right]$ diminishing the wettability of the electrolyte on the anode. This prevents further $F_{2}$ gas generation and results in a sharp rise in the anode potential accompanied by a decrease in the current. ${ }^{\left[{ }^{[c]}\right]}$ To investigate this phenomenon in the CsF-2.45HF system containing $\mathrm{CuF}_{2}$ (33.5 $\mathrm{g}$ was added to $1 \mathrm{~kg}$ of $\mathrm{CsF}-2.45 \mathrm{HF}$ ), the average anode potentials of the glass-like carbon, graphite, and $\mathrm{Ni}$ electrodes were obtained through galvanostatic electrolysis at current densities in the $100-500 \mathrm{~mA} \mathrm{~cm}^{-2}$ range (5 min for each current density) as shown in Figure 3 . In the glass-like carbon electrode cells, a linear increase in the anode potential is observed with increasing current density. No sharp spikes are seen, attributing the behaviour to the influence of DC-IR exclusively. On the other hand, the increasing graphite anode potential with increasing current density becomes even more exacerbated at elevated current densities. However, the occurrence of the "anode effect" was not observed, suggesting that the fluorination of the graphite electrode at high current densities is not drastic enough to cause significantly high resistance at the electrode surface. This observation is contrary to the behavior of graphite electrodes in the KF-2HF molten salt at $90{ }^{\circ} \mathrm{C} .{ }^{[8 c]}$ After electrolysis, the graphite electrode surface was found to have cracks and exfoliations unlike the glass-like carbon, suggesting the latter facilitates a more stable electrolysis.

For the present electrolysis, the $\mathrm{Ni}$ electrode appears to be a more feasible electrode candidate, as it is more economical than the glass-like carbon. Previous works have reported poor $F_{2}$ gas generation when a $\mathrm{Ni}$ electrode is used in the mediumtemperature KF-2HF molten salt electrolysis, ${ }^{[8 a, 17]}$ on account of nickel fluoride dissolution into the electrolyte that causes sludge deposition in the cell. However, in the present system, the low

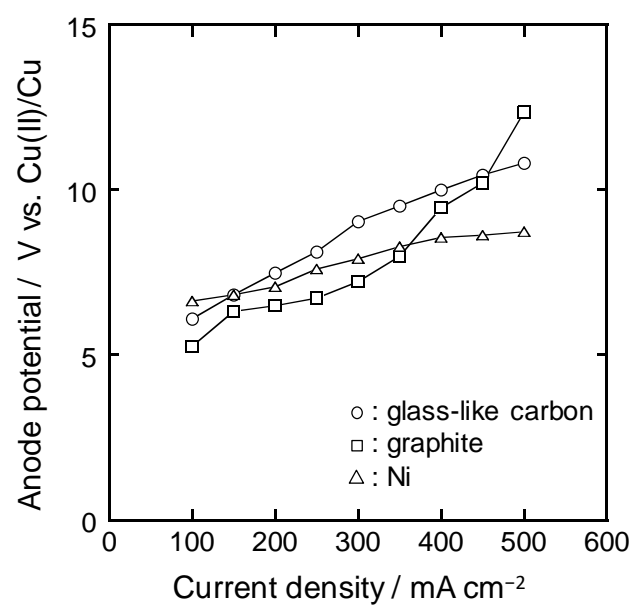

Figure 3. Average anode potentials of the glass-like carbon, graphite, and $\mathrm{N}$ electrodes during galvanostatic electrolysis of the CsF-2.45HF molten salt electrolyte containing $\mathrm{CuF}_{2}\left(\mathrm{CuF}_{2}\right.$ saturated) $(5 \mathrm{~min}$ for each current density from 100 to $500 \mathrm{~mA}$ ). The anode effect, characterized by a sharp increase in the anode potential, is not observed in all cases. 
solubility of nickel fluorides at room temperature and the high kinetic barrier of nickel fluoride formation played critical roles in its utilization as an anode material. A similar mechanism occurs in the Simons process, where a Ni electrode effectively works as an anode in anhydrous HF at room temperature to oxidize organic compounds. ${ }^{[18]}$

For further insight into the electrolytic behavior of the present system, in-depth investigations (quantitative analysis, purity test, and long-term electrolysis) were performed on a larger cell (100 $\mathrm{cm}^{3}$ ) comprising a Cu mesh cathode (apparent surface area 60 $\left.\mathrm{cm}^{2}\right)$, a $\mathrm{Cu}$ wire reference electrode, and a $\mathrm{Ni}$ anode $\left(7.0 \mathrm{~cm}^{2}\right)$ immersed in CsF-2.45HF containing $\mathrm{CuF}_{2}$ as shown in the schematic diagram (Figure S7).

Quantitative analysis was performed by measuring the volume of the gas evolved at the anode. Although the two-electron per gas molecule process (Equation 5) can be used to calculate the volume of $F_{2}$ gas evolved at the anode, possible side reactions causing gas evolution $\left(\mathrm{O}_{2}\right.$ or $\mathrm{OF}_{2}$ gas) could occur at the anode due to $\mathrm{H}_{2} \mathrm{O}$ contamination. The side reactions entailing four electrons per gas molecule in accordance with Equations (7) and

(a)

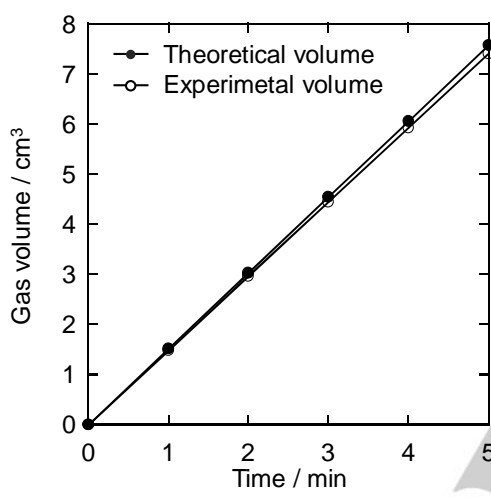

(b)

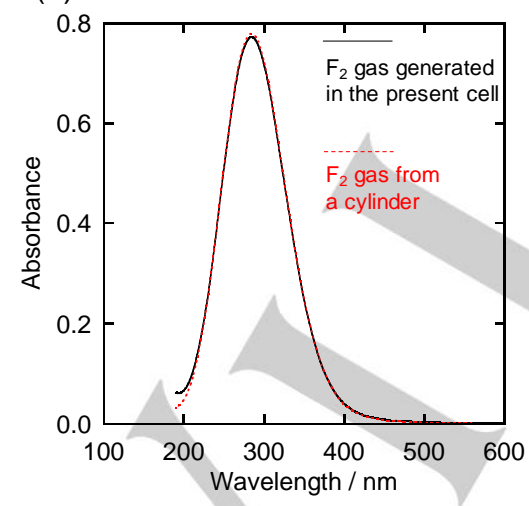

Figure 4. Relationship between the electrolysis duration (time) and the volume of the gas generated at the anode during galvanostatic electrolysis of the $\mathrm{CsF}$ $2.45 \mathrm{HF}$ molten salt electrolyte containing $\mathrm{CuF}_{2}\left(\mathrm{CuF}_{2}\right.$ saturated) at $200 \mathrm{~mA} \mathrm{~cm}^{-2}$. Surface area: $7.0 \mathrm{~cm}^{2}$ for the Ni plate anode and $60 \mathrm{~cm}^{2}$ for the $\mathrm{Cu}$ mesh cathode. The gas volume was measured by an $\mathrm{F}_{2}$-resistant gas burette. (b) An ultraviolet-visible spectrum of $F_{2}$ gas (black) generated through the present method using the $\mathrm{Ni}$ electrode in the $\mathrm{CsF}-2.45 \mathrm{HF}$ molten salt electrolyte containing $\mathrm{CuF}_{2}$. Surface area: 7.0 and $60 \mathrm{~cm}^{2}$ for the $\mathrm{Ni}$ anode and $\mathrm{Cu}$ cathode, respectively. The purity was calculated based on the calibration using $F_{2}$ gas (red) from a commercial cylinder (purity $99 \%$ ). Gas pressure: $40 \mathrm{kPa}$. The $\mathrm{F}_{2}$ gas was generated by galvanostatic electrolysis at $200 \mathrm{~mA}$ for $45 \mathrm{~min}$ using the $100 \mathrm{~cm}^{3}$ cell (Figure S7). See the literature for the details on the Central Glass method and UV-vis spectrum of $F_{2}$ gas. ${ }^{[1-4]}$
(8) would lead to lower volumes of $F_{2}$ gas than envisioned in Equation 5. Therefore, to estimate the efficiency of $F_{2}$ gas evolution in the present system, gas volume measurements would be necessary.

$2 \mathrm{H}_{2} \mathrm{O} \rightarrow \mathrm{O}_{2}+4 \mathrm{H}^{+}+4 \mathrm{e}^{-}$

$\mathrm{H}_{2} \mathrm{O}+2 \mathrm{HF} \rightarrow \mathrm{OF}_{2}+4 \mathrm{H}^{+}+4 \mathrm{e}^{-}$

The volume of the gas evolved at the $\mathrm{Ni}$ anode during galvanostatic electrolysis of $\mathrm{CuF}_{2}$ in $\mathrm{CsF}-2.45 \mathrm{HF}$ at $200 \mathrm{~mA}$ was measured using a PFA gas burette with poly(chlorotrifluoroethylene) oil. The relationship between the gas volume and the electrolysis duration (time) is shown in Figure 4(a). The gas volume is proportional to electrolysis duration with a slight deviation from the ideal line, in accordance with Faraday's law, which suggests a lower efficiency possibly resulting from the above-mentioned side reactions. Infrared spectrum of the $F_{2}$ gas evolved at the anode identified a very limited amount of $\mathrm{OF}_{2}$ impurity (see Figure S8 for the IR spectrum with that before preelectrolysis. Note that $\mathrm{O}_{2}$ gas cannot be detected through infrared spectroscopy). The Central Glass method, ${ }^{[19]}$ using UV-visible spectroscopy based on the absorption of $F_{2}$ gas at $\sim 280 \mathrm{~nm}$, was employed for a more accurate evaluation of $F_{2}$ gas purity. ${ }^{[20]}$ Figure 4 (b) shows the UV-visible spectrum of the $F_{2}$ gas obtained from electrolysis at $200 \mathrm{~mA}$ alongside a typical spectrum of cylinder-supplied $F_{2}$ gas. A comparison of the integrated areas of the absorption peaks revealed the purity of generated $F_{2}$ gas to be $99 \%$.

(a)

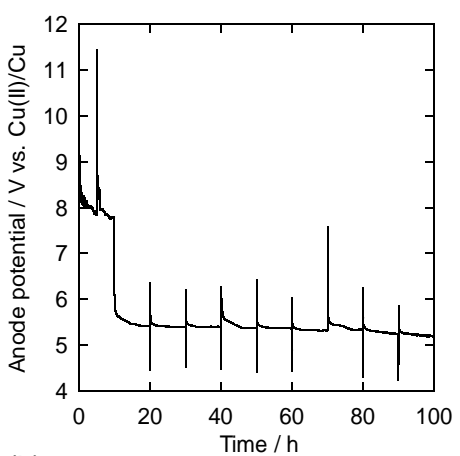

(b)

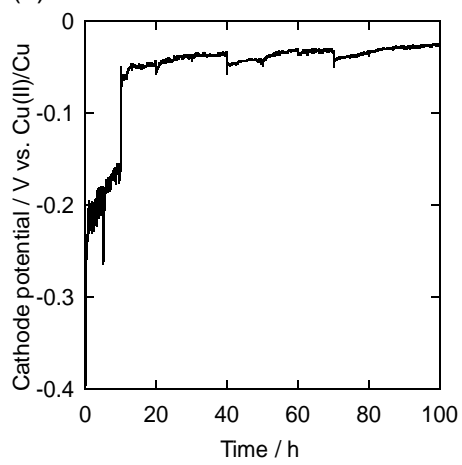

Figure 5. (a) Anode and (b) cathode potentials during long-term intermittent galvanostatic electrolysis of the CsF-2.45HF molten salt electrolyte containing $\mathrm{CuF}_{2}\left(\mathrm{CuF}_{2}\right.$ saturated) for $100 \mathrm{~h}(5 \mathrm{~h} \times 2$ at $500 \mathrm{~mA}$ and $10 \mathrm{~h} \times 9$ at $100 \mathrm{~mA})$ in the $100-\mathrm{cm}^{3}$ electrolytic cell. Surface area: $7.0 \mathrm{~cm}^{2}$ for the Ni plate anode and $60 \mathrm{~cm}^{2}$ for the $\mathrm{Cu}$ mesh cathode. 
(a)

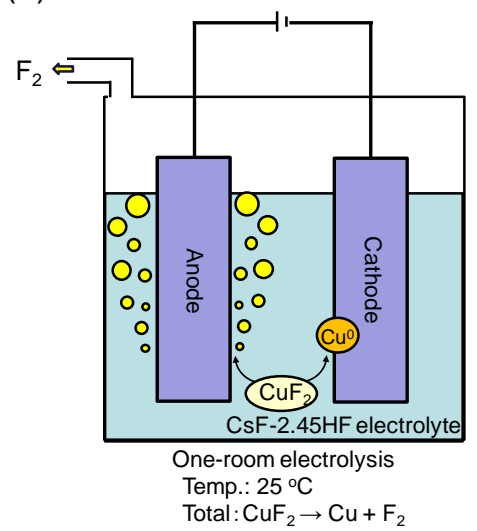

(b)

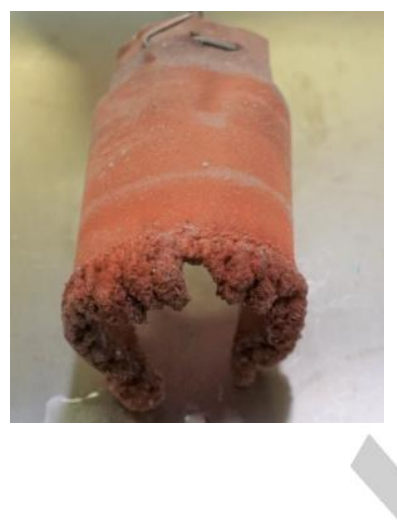

(c)

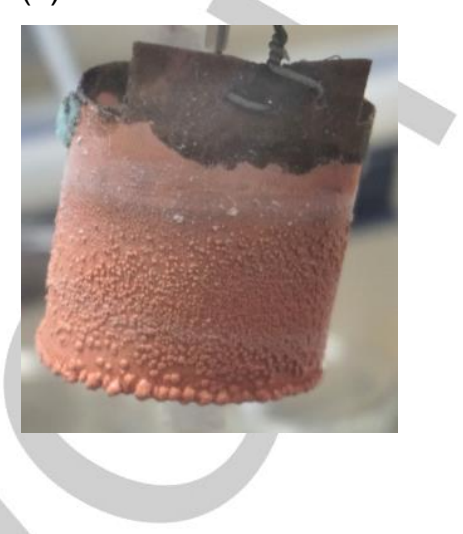

Figure 6. (a) A schematic drawing of a one-compartment electrolytic cell $\left(100 \mathrm{~cm}^{3}\right)$ comprising CsF-2.45HF molten salt containing CuF $\left(\mathrm{CuF}_{2}\right.$ saturated). The cell configuration is similar to the one in Figure 1 (c), with the distinction of the partitioning skirt between the cathode and anode. This setup results in significantly reduced bulk resistance, as shown in Figure S10. An image of Cu metal deposited on the cathode (b) after 100-hour electrolysis with a skirt (Figure 1 (c) and Figure 5 (b)) and (c) after 40-hour electrolysis without a skirt (Figure 6 (a) and Figure S9 (b)).

Long term analysis of the large $\left(100 \mathrm{~cm}^{3}\right)$ cell was conducted for $100 \mathrm{~h}$ (current: $500 \mathrm{~mA}$ for the first $10 \mathrm{~h}$ and $100 \mathrm{~mA}$ for $90 \mathrm{~h}$ thereafter). The electrolysis was performed for $5 \mathrm{~h}$ per day for the initial $10 \mathrm{~h}$ followed by $10 \mathrm{~h}$ per day for the subsequent $90 \mathrm{~h}$, for 9 days to demonstrate the possible intermittent operation in practical cells. The resulting $\mathrm{Ni}$ anode and $\mathrm{Cu}$ cathode potentials are shown in Figure 5 (a) and (b). Although the anode potential is observed to spike at the beginning of each electrolysis (due to high resistance at the electrode surface), it promptly decreases in a short period. Electrolysis at $500 \mathrm{~mA}$ is characterized by a gradual decrease in the anode potential, which stabilizes between 5.5 and $5.0 \mathrm{~V}$ at $100 \mathrm{~mA}$ with no sign of the anode effect. The cathode potential remains above $-0.3 \mathrm{~V}$ at $500 \mathrm{~mA}$ and over -0.1 $V$ at $100 \mathrm{~mA}$, suggesting safe electrolysis with no generation of $\mathrm{H}_{2}$ gas (see Figure 2(b)).

Since $\mathrm{H}_{2}$ gas is not generated at the cathode and the reaction between the $\mathrm{Cu}$ metal and $\mathrm{F}_{2}$ gas is negligible, one-compartment electrolysis (wherein the skirt between the cathode and anode is removed) can be accomplished in the present system (see Figure 6(a) and Figure S7(a) in the Supporting Information, for the schematic drawing of the one-compartment electrolysis cell). Although this electrolysis cell requires strict monitoring of the cathode potential to ensure no $\mathrm{H}_{2}$ gas is evolved for safety reasons, the simplified cell construction and the reduced ohmic drop caused by electrolyte bulk resistance makes it advantageous to implement. Moreover, without the skirt which geometrically drives current concentration to the bottom part of the electrodes, a larger effective electrode area can be achieved, reducing the actual current density at both electrodes.

A trial of the one-compartment electrolysis using the $100-\mathrm{cm}^{3}$ cell over $40 \mathrm{~h}$ at $100 \mathrm{~mA}$ demonstrated stable electrode potentials (see Figure S9 for detailed electrochemical behavior). Electrochemical impedance spectroscopy performed on cells with and without the skirt revealed a significant difference in the ohmic drops of the $\mathrm{Ni}$ electrodes ( $7.5 \Omega$ with a skirt and $1.7 \Omega$ without a skirt), affirming the electrochemical benefit of the one- compartment electrolysis (Figure S10 for the Nyquist plots of the electrochemical systems with and without the skirt). A closer inspection of the $\mathrm{Cu}$ metal deposition on the $\mathrm{Ni}$ electrodes from the cells with and without the skirt reveals bulkier deposition at the bottom of the electrode used with the skirt (Figure 6 (b)), indicative that the current flows from the bottom to avoid the skirt. On the other hand, the electrode used without the skirt, portrays a uniform distribution of $\mathrm{Cu}$ metal deposit on the entire cathode, indicating a more homogeneous current flow between cathode and anode (Figure 6 (c)).

\section{Conclusion}

In this study, we report room temperature $F_{2}$ gas generation for small-scale lab and industry applications. With simple peripheral equipment, $\mathrm{Cs}\left[(\mathrm{FH})_{2.45} \mathrm{~F}\right]$ molten salt, which was reported over 80 years ago, facilitates $F_{2}$ gas generation upon addition of $\mathrm{CuF}_{2}$. Preliminary screening of selected metal fluorides demonstrates improved safety when $\mathrm{CuF}_{2}$ is utilized as it prevents $\mathrm{H}_{2}$ gas generation. Although the anode effect does not occur on graphite and glass-like carbon electrodes even at high current densities during electrolysis, a slight increase in the anode potential is observed in graphite, suggesting the occurrence of surface fluorination. Herein we note that unlike in mediumtemperature KF-2HF molten salt cells, the Ni electrode exhibits a stable electrolysis behavior in $\mathrm{Cs}\left[(\mathrm{FH})_{2.45} \mathrm{~F}\right]$ owing to its low solubility at room temperature. Besides, higher durability and lower cost make it a more auspicious electrode choice. The proposed electrolysis cell not only demonstrates stable intermittent electrolysis of $\mathrm{CuF}_{2}$ performed over $100 \mathrm{~h}$ but also generated $F_{2}$ gas with a high purity of $99 \%$, albeit with traces of $\mathrm{OF}_{2}$ impurity. For prolonged $\mathrm{F}_{2}$ gas generation, strategies such as replenishing $\mathrm{CuF}_{2}$ upon depletion (provided it is handled under dry conditions) or replacing the entire electrolytic cell (mechanical exchange), could be undertaken. Recovery of the cathodically 
deposited $\mathrm{Cu}$ metal to $\mathrm{CuF}_{2}$ may be an important process from a certain scale of generation. Although the theoretical amount and maximum rate of $F_{2}$ gas generated in the present $100-\mathrm{cm}^{3}$ cell is $2.28 \mathrm{dm}^{3}$ and $0.232 \mathrm{dm}^{3} \mathrm{~h}^{-1}$, respectively (see Supporting Information for their estimation), it can be increased by scaling up the cell and electrode sizes, depending on the type of application. Compared with the previously known chemical synthesis of $F_{2}$ (see Introduction for details), which is also a possible method for small-scale production, facile control of the amount of $F_{2}$ gas by electrochemical parameters is a significant advantage of the present method. The gas generation process without directly handling reactive fluorides such as $\mathrm{SbF}_{5}$ is also beneficial in some practical use.

We believe that this facile electrolysis process is a groundbreaking approach to small-scale and on-demand $F_{2}$ gas generation that will open up new horizons for the exploration and utilization of $F_{2}$ gas in a wide range of domains such as fundamental studies in fluorine chemistry, direct fluorination of organic compounds, and surface treatment of functional materials including semi-conductors. Future works focused on improving the proposed cell configuration and expanding the fields of $F_{2}$ gas are highly expected.

\section{Acknowledgements}

This work was supported by JSPS KAKENHI Grant Number 17K19175. The authors thank Ueki Corporation for the cell design and Central Glass Co., Ltd. for the $F_{2}$ purity test.

Keywords: Fluorine $\cdot$ Fluorides $・$ Electrolysis $\cdot$ Small-scale production

[1] (a) H. W. Roesky, Efficient Preparations of Fluorine Compounds, John Wiley \& Sons, Hoboken, 2013; (b) K. Seppelt, Chem. Rev. 2015, 115 1296-1306; (c) P. Laszlo, G. J. Schrobilgen, Angew. Chem. Int. Ed. 1988 27, 479-489; Angew. Chem. 1988, 100, 495-506; (d) O. V. Boltalina, T. Nakajima, New Fluorinated Carbons: Fundamentals and Applications, 1st, ed. A. Tressaud (Series Ed.), Elsevier, London, 2016.

[2] (a) G. Sandford, J. Fluorine Chem. 2007, 128, 90-104; (b) C. B. McPake, G. Sandford, Org. Process. Res. Dev. 2012, 16, 844-851; (c) D. D. DesMarteau, J. Fluorine Chem. 2006, 127, 1467-1470; (d) P. A Champagne, J. Desroches, J. D. Hamel, M. Vandamme, J. F. Paquin, Chem. Rev. 2015, 115, 9073-9174; (e) R. D. Chambers, J. Hutchinson, G. Sandford, J. Fluorine Chem. 1999, 100, 63-73.

[3] (a) A. Tressaud, E. Durand, C. Labrugere, A. P. Kharitonov, L. N. Kharitonova, J. Fluorine Chem. 2007, 128, 378-391; (b) V, Dybbert, S. M. Fehr, F. Klein, A. Schaadt, A. Hoffmann, E. Frei, E. Erdem, T. Ludwig, H. Hillebrecht, I. Krossing, Angew. Chem. Int. Ed. 2019, 58, 1293512939; Angew. Chem. 2019, 131, 13069-13073.

[4] (a) H. R. Moissan, C. R. Hebd. Seances Acad. Sci. 1886, 75, 1543-1544; (b) H. R. Moissan, C. R. Hebd. Seances Acad. Sci. 1886, 103, 202-205 (c) M. E. Weeks, J. Chem. Educ. 1932, 9, 1915-1939; (d) A. Tressaud, Angew. Chem. Int. Ed. 2006, 45, 6792-6796; Angew. Chem. 2006, 118, 6946-6950.

[5] K. O. Christe, Inorg. Chem. 1986, 25, 3721-3722.

[6] (a) J. S. A. D. Gunne, M. Mangstl, F. Kraus, Angew. Chem. Int. Ed. 2012 51, 7847-7849; Angew. Chem. 2012, 124, 7968-7971; (b) V. R. Celinski, M. Ditter, F. Kraus, F. Fujara, J. S. A. D. Guenne, Chem. Eur. J. 2016, 22, 18388-18393.

[7] (a) S. Mattsson, B. Paulus, F. A. Redeker, H. Beckers, S. Riedel, C. Muller, Chem. Eur. J. 2019, 25, 3318-3324; (b) S. I. Iviev, A. J. Karttunen, M. Hoelzel, M. Conrad, F. Kraus, Chem. Eur. J. 2019, 25, 3310-3317.
[8] (a) R. J. Ring, D. Royston, A Review of Fluorine Cells and Fluorine Production Facilities, in Australian Atomic Energy Commission Research Estrablishment, Lucus Heights, 1973; (b) G. H. Cady, D. A. Rogers, C. A. Carlson, Ind. Eng. Chem. 1942, 34, 443-448; (c) H. Groult, J. Fluorine Chem. 2003, 119, 173-189.

[9] G. H. Cady, J. Am. Chem. Soc. 1934, 56, 1431-1434.

[10] F. C. Mathers, P. T. Stroup, Trans. Am. Electrochem. Soc 1934, 66, 245252.

[11] R. V. Winsor, G. H. Cady, J. Am. Chem. Soc. 1948, 70, 1500-1502.

[12] (a) K. Matsumoto, J. Ohtsuki, R. Hagiwara, S. Matsubara, J. Fluorine Chem. 2006, 127, 1339-1343; (b) S. Kohara, M. Takata, K. Matsumoto, R. Hagiwara, K. Suzuya, H. Morita, J. E. Siewenie, C. J. Benmore, J. Chem. Phys. 2008, 129; (c) R. Hagiwara, Y. Nakamori, K. Matsumoto, Y. Ito, J. Phys. Chem. B 2005, 109, 5445-5449; (d) R. Hagiwara, K. Matsumoto, Y. Nakamori, T. Tsuda, Y. Ito, H. Matsumoto, K. Momota, J. Electrochem. Soc. 2003, 150, D195-D199.

[13] K. W. Pratt, W. F. Koch, Y. C. Wu, P. A. Berezansky, Pure. Appl. Chem. 2001, 73, 1783-1793.

[14] A. Noda, K. Hayamizu, M. Watanabe, J. Phys. Chem. B 2001, 105, $4603-4610$

[15] L. Niedzicki, S. Grugeon, S. Laruelle, P. Judeinstein, M. Bukowska, J. Prejzner, P. Szczecinski, W. Wieczorek, M. Armand, J. Power Sources 2011, 196, 8696-8700.

[16] (a) N. Watanabe, T. Nakajima, H. Touhara, Graphite Fluorides, Elsevier, Amsterdam, 1988; (b) A. Hamwi, K. Guérin, M. Dubois, Fluorineintercalated Graphite for Lithium Batteries, Ch. 17, in Fluorinate Materials for Energy Conversion T. Nakajima, H. Groult (Ed.), Elsevier, Oxford, 2005, pp. 369-395.

[17] H. R. Neumark, Trans. Electrochem. Soc. 1947, 91, 367-385.

[18] (a) L. Conte, G. P. Gambaretto, J. Fluorine Chem. 2004, 125, 139-144; (b) M. Drisch, L. A. Bischoff, J. A. P. Sprenger, P. T. Hennig, R Wirthensohn, J. Landmann, S. Z. Konieczka, M. Hailmann, N. V. Ignat'ev, M. Finze, Chem. Eur. J. 2020, 26, 11625-11633.

[19] (a) T. Miyazaki, I. Mori, T. Umezaki, S. Yonezawa, J. Fluorine Chem 2019, 219, 55-61; (b) I. Mori, M. Kaichi, Japanese Pat. JPB20084211983, 2008.

[20] (a) R. K. Steunenberg, R. C. Vogel, J. Am. Chem. Soc. 1956, 78, 901902; (b) R. Holland, J. L. Lyman, J. Quant. Spectrosc. Radiat. Trans. $1987,38,79-80$ 


\section{Entry for the Table of Contents}

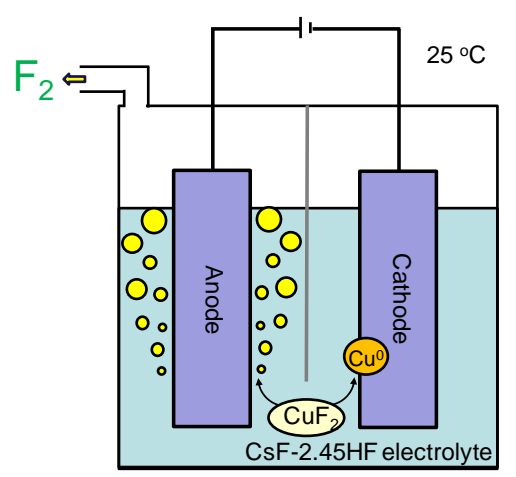

Fluorine gas generation is achieved at room temperature through the electrolysis of $\mathrm{CuF}_{2}$ in a CsF-2.45HF molten salt without the evolution of $\mathrm{H}_{2}$ gas. Stable electrolysis with a Ni anode over $100 \mathrm{~h}\left(\mathrm{~F}_{2}\right.$ purity over $\left.99 \%\right)$ with potential operation using onecompartment electrolysis lead to a safe and propitious mechanism for high-purity fluorine gas generation for small-scale lab and industrial applications. 